\title{
A New Land Equipment, Commercial Parks, Criteria and Parameters of Design - Analysis of Spain's Experience
}

\author{
Juan Carlos García Saugar, Jose Maríadel Campo, and Juan A. Santamera
}

\begin{abstract}
Industrial revolution, in all its stages, marked a change that fully affected commercial activity in the city, gradually producing a radical spacing between places of production of manufactured goods and exchange ones. The latter are specializing, from the first trades groups in small markets, to one of the most sophisticated forms of retail spaces at present, the Commercial Park, which in Spain is becoming increasingly important. Based on that currently, there are no conclusive studies on how to approach these new spaces. It is for this reason that this research is performed, to obtain a definition of the term and sizing parameters.
\end{abstract}

Index Terms-Gross lettable area (GLA), commercial park, mall, Spain.

\section{INTRODUCTION}

The concept of Commercial Park has been running parallel to that of the Shopping Centre, at least in Europe. In all classifications Commercial Parks have generally been considered as a type of Shopping Centre with special characteristics, as it can be seen in the definition by the Spanish Shopping Centres Association (AECC) [1], which says, "A specialized format of Shopping Centre, which consists in a commercial activity Area with a common urbanized space, retail sale activity, and shaped mainly by medium and large shopping areas."

\section{DEVELOPMENT}

Three stages or processes have been covered in order to reach the point of development and specialization of today. One of the first forms of human relationships has been the trade of objects and goods from the moment the first human groups settlements were established. Currency has been one of those forms whose value depended from necessity.

Obviously, with the common purpose of adding synergies, traders started unconsciously grouping together to sell their products, then they started learning from each other and at the same time rivalry was promoted.

A great variety of factors have been needed and a long way has been made for the trade forms and trade groups to reach the level of today's improvement.

To start with, we mention the first social groups that began to develop some form of trade market such as:

Greek Stoas: They were covered architectural spaces protected from the sun and rain proper for the social life of

Manuscript received December 31, 2014; revised May 5, 2015.

The authors are with the Technical University of Madrid (UPM), Spain (e-mail: josemaria.delcampo@upm.es).
Mediterranean cities. They sometimes were full of stalls that allowed trade activity, as in Fig. 1.

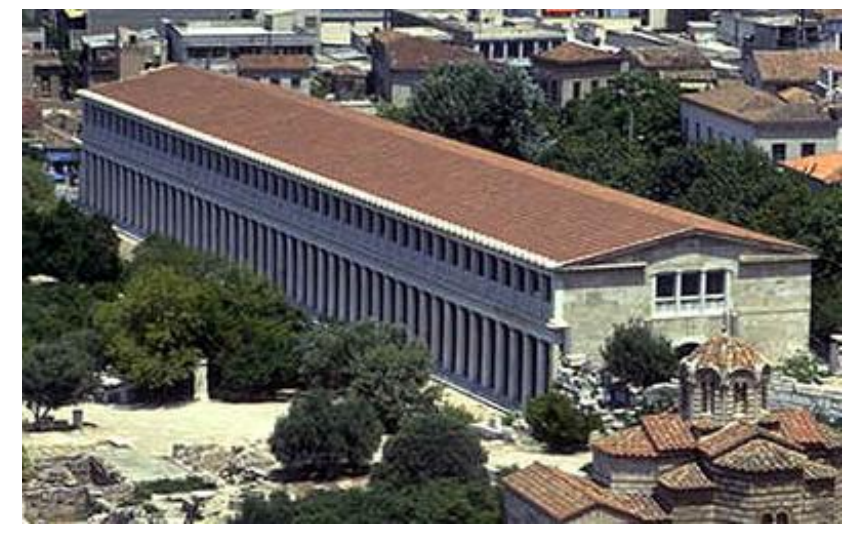

Fig. 1. Attalos Stoa Athens.

Roman Forums: as in Fig. 2 were another important type of trade present in every city in the ancient world. These forums were used not only for legal agreements, business transactions or political activity, but also for playing ground, theatre, gladiatorial combats and chariot racing.

Another example is the Great Bazaar of Istambul, as in Fig. 3 lately rebuilt its origin is dated in 1464, right after the fall of Constantinople following the Muslim conquest by Sultan Mehmed II.

In this period, new buildings and services were raised, like the roofed bazaars or Bedestein. In 1461, Mehmed II ordered to build a new Bedestein, organizing the streets according to the type of fabric in sale and it was named "Sandal Bedestein" or "Silk Bazaar." As other trades soon started to flourish such as safe custody of securities and values, jewelry, gold, carpets, etc., the bazaar rapidly became the centre of the economic life of the Ottoman Empire.

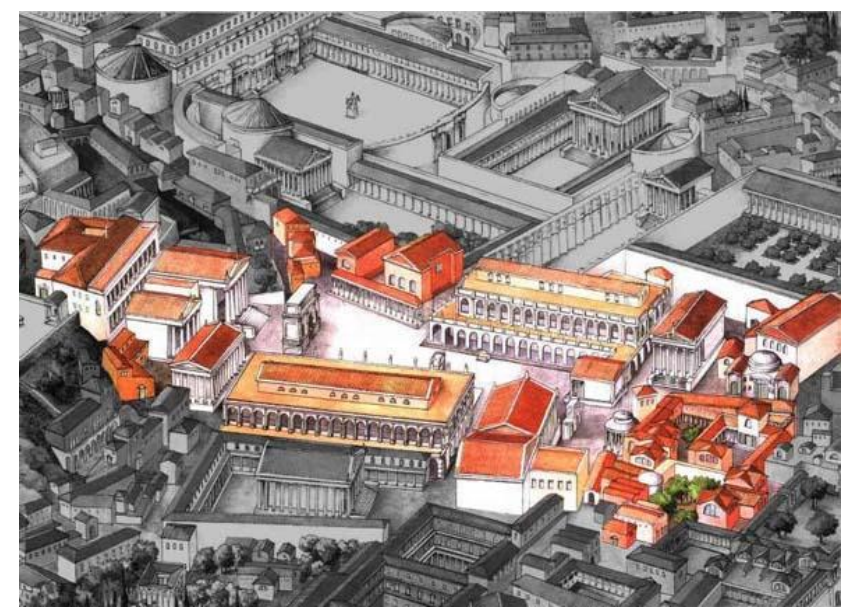

Fig. 2. Roman forum 
It was the industrial revolution with its different phases what brought the division of manufacture areas with areas of sale and the improvement of the trade distribution, and it began with it the process of technological, social and economic change that caused the goods to occupy the centres of the cities where the commercial life was held, and then they started to grow upwards from ground floor, allowing the setting of shops, signs, bill boards, lights, etc., and whole skill-specialized buildings [2] which eventually would evolve in the Paris Passages.

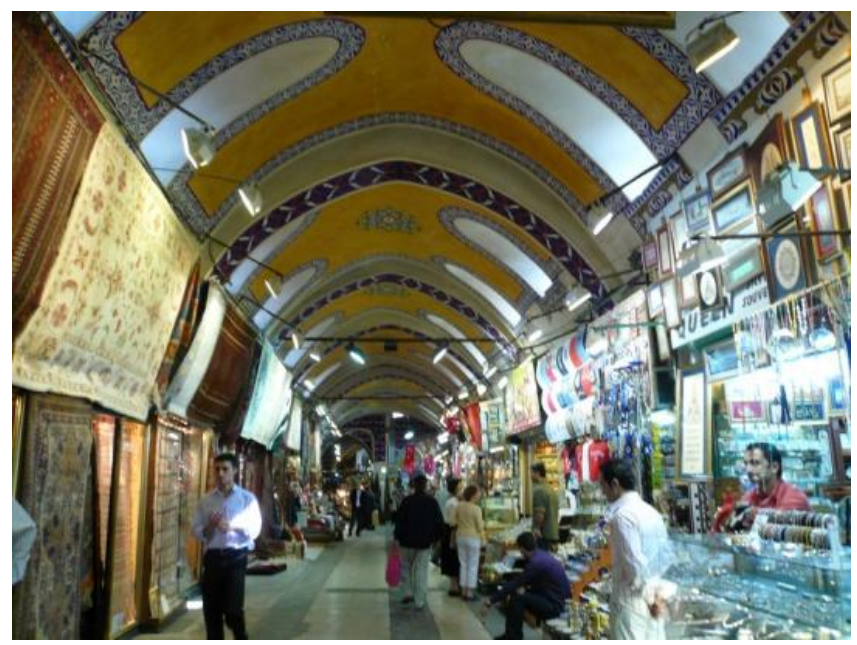

Fig. 3. Great Bazzar of Istambul view.

The English Arcades or the Modern Galleries and Passages distinguished as the most representative and innovative ones.

One of the most important is The Burlington Arcade, as in Fig. 4, which was opened in 1819 It is a covered shopping arcade in London that runs behind Bond Street from Piccadilly through to Burlington Gardens. It is one of the precursors of the mid-19th-century European shopping gallery and the modern Shopping Centre.

The Burlington Arcade was built "for the sale of jewellery and fancy articles of fashionable demand, for the gratification of the public." Very important items that give us an idea that a new vision of the business, because the managers start to think that they have to open the stores to the clients.

It can't be missed the Galleria Vittorio Emanuelle II, as in Fig. 5, in Milan, which meant the beginning of a real "shopping revolution." It was designed in 1861 and built by Giuseppe Mengoni between 1865 and 1877. It was larger in scale than its predecessors and meant an important development in glazed and enclosed shopping malls being a direct prototype.

130 year after its opening, the elegant four-storey gallery is still containing luxury retailers selling haute couture, jewelry, books and paintings, as well as restaurants, cafés, and bars. It is still one of the most vanguard malls within the trade and hotel industry.

However, it was the invention of the piston engine that made the big difference, as we can see in Fig. 6, Fig. 6. Development of trade forms., which doubtlessly meant the beginning of the second industrial revolution and the consolidation of the development of the trade business in
North America as well as in Europe. This development contributed to the birth of the Commercial Park format and it was design to allow private car traffic. In Spain, this process did not arrive until the years 1959-1960 where a turning point can be set [3]. Additionally, private vehicles were going to determine trading practices which, as it can be seen, began to adapt to new commuting ways and the users' independence. This new phenomenon was also going to be modified by the new methods of transportation. Following Juan A. Santamera [4] in one of his conferences, "cars associated with the piston engine and its wider use has brought a new urbanization, spreading the city limits in all directions of its territory."

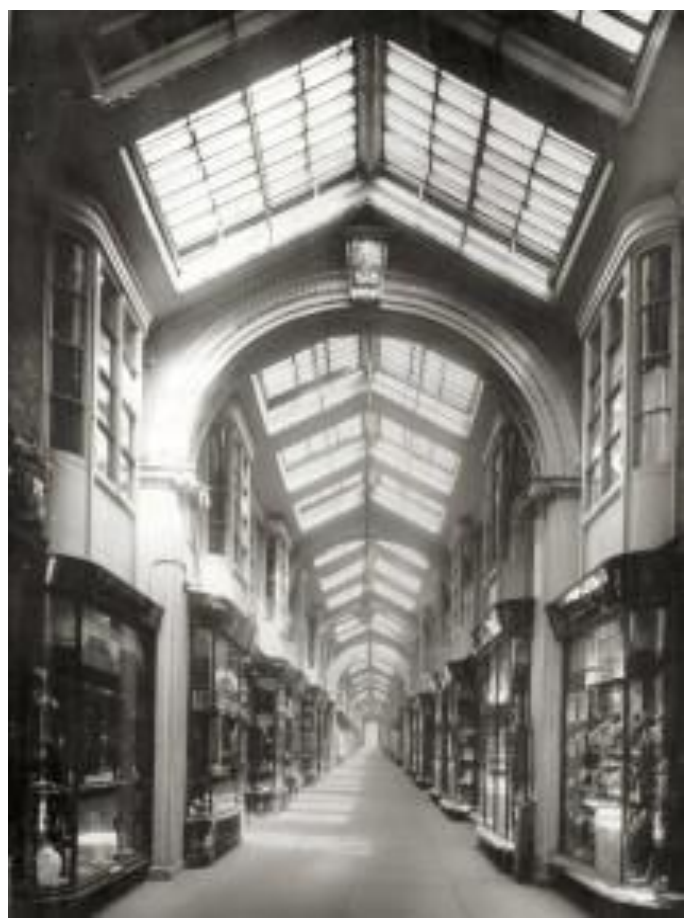

Fig. 4. Burlintong Arcade London 1819.

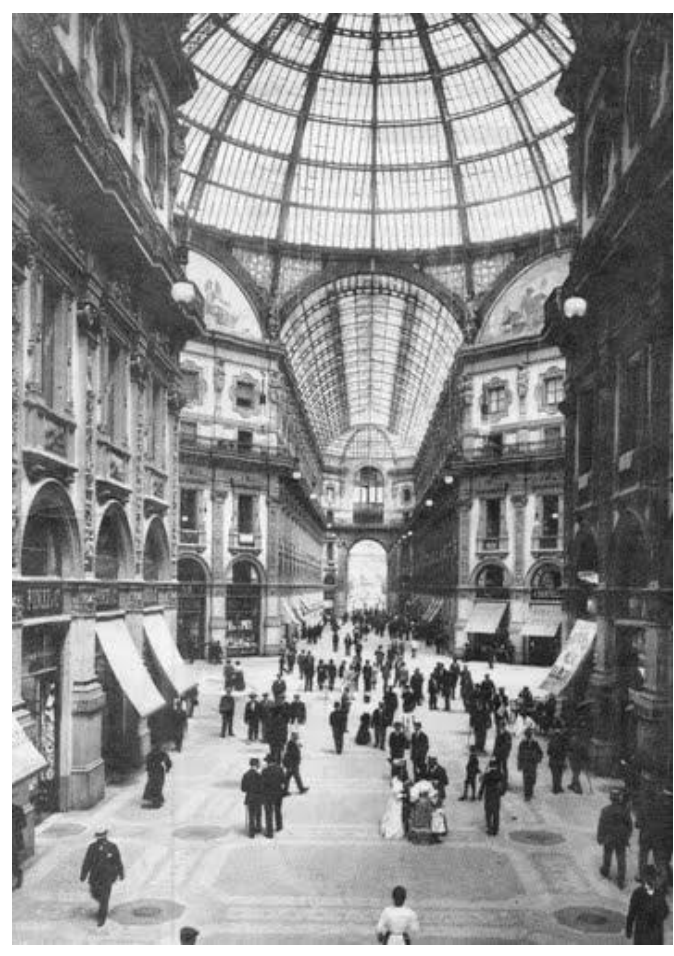

Fig. 5. Galleria vittorio emanuele II, Milán 1880. 

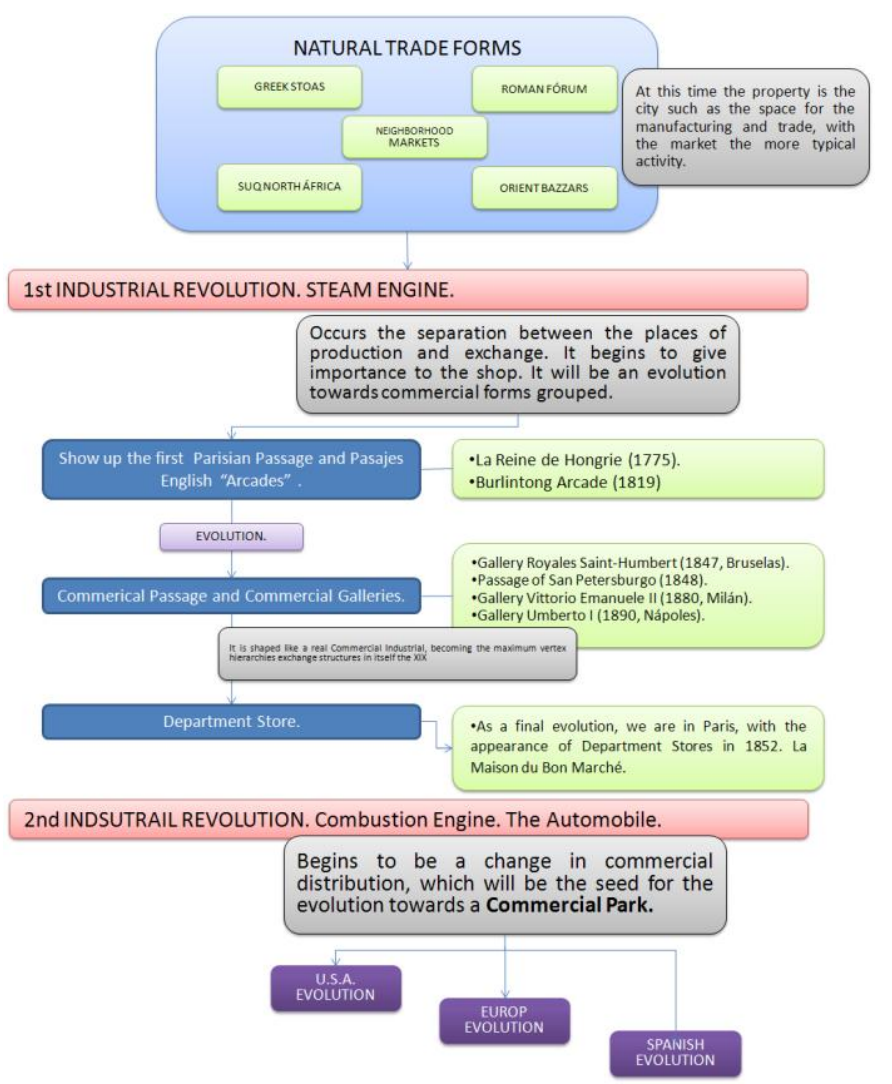

Fig. 6. Development of trade forms.

\section{SPANISH DEVELOPMENT}

It was not until 1960 in Spain when traditional trade gave way to building the bases of massive distribution which appears as a consequence of migratory movements, income increase and tourism development. However, it was not until 1970 when the period of massive distribution got off with a good start [5].

At present, in Spain we are witnessing, based on Santesmases' life cycle theory [6], a maturity time in the development of Commercial Park. From the opening of the first Commercial Park in Spain (Parque Comercial Carrefour Elche, Alicante, 1983), a rapid growth can be registered in the openings of new centers. 2001 marks the turning point of the opening growth curve, as it can be seen in Fig. 7. Number of commercial parks development in Spain.

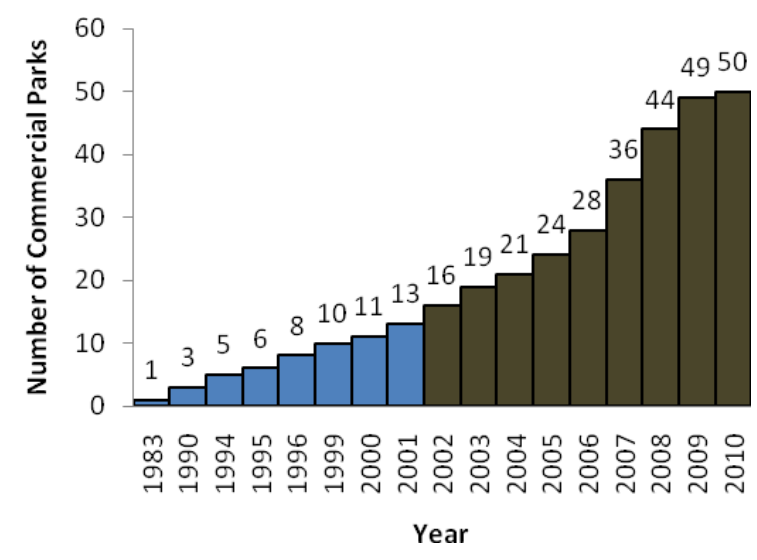

Fig. 7. Number of commercial parks development in Spain per year.

\section{OBJECTIVES OF THE STUdy}

Based on the present situation, the author has considered thoughtfully about the development of the meaning of Commercial Parks. The motive of the study is the parameters of their characteristics.

In order to do this, a study will be made, firstly about the development of Commercial Parks in Spain, being characterized according to location, opening date, and Gross Lettable Area (GLA), which in the trade business means the Useful Shopping Area, That is, the area for selling goods or services. It is the area liable to generate exploitation incomes (not considering public spaces and parking lots). Next, a study of 17 emblematic Spanish Commercial Parks will be made, in which we will take into account its location in relation to population, public and private bypasses, areas and functions included in the proper Development Plan they belong to, to focus immediately on the general organization parameters of the Parks, such as:

1) Suitability for building, minimum allotment, occupancy ratio, height

2) Trade Areas.

3) Parking spots.

4) GLA and relation to shopping area, suitability for building and parking lots.

Off-plan measures will be made for urbanized areas and parking lots, so in this way and together with the building project data, a classification of former scales and ratios of each of them will be obtained.

In this way, some indicators can be obtained as a guide to localization, territory planning and drafting of these new land facilities.

In the second place, a new definition of Commercial Park will be offered with a clear, solid meaning that will allow making it different according to the relevance it has lately acquired up to these days, and it is:

"A Commercial Park is a complex of independent stores that have been planned and developed by one or several firms with unified criteria whose size, trade mixture, common services and social activities are environmentally integrated in its surroundings with a standing single image and management; they must have a common urbanized space, commercial activity with interconnecting walkways and large free areas."

\section{REFERENCES}

[1] A.E.C.C. Technical Committee of the Spanish Asociation of Commercial Centres. (2006). [Online]. Available: http://www.aedecc.com

[2] P. Sica, "History of urban development. XIX Century," Ed. Research Institute of Local Goverment, Madrid, 1981.

[3] A. A. Rebollo and J. R. Casares, "Commercial distribution," Civitas Library Economy and Business Economy Collection, $2^{\text {nd }}$ ed., Madrid, 2000.

[4] J. A. Santamera, "Tourism, territory and sustainable development," presented at the 8th Wcce General Assembly, Santiago de Cuba, Cuba, October 11, 2013

[5] P. Cuesta, "Growth strategy of the business commercial distribution of consumer goods operating in Spain," Ph.D. dissertation, Dept. Finance and Marketing Research, Faculty of Economics and Business, Autonomous University of Madrid, 2001.

[6] M. Santesmases, Marketing and Strategies, $4^{\text {th }}$ ed., Pyramid, Madrid, 1999. 


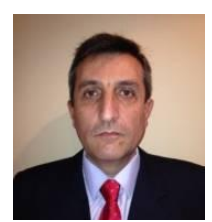

Juan Carlos Garcia Saugar was born in Spain in 1964. He is a master in civil engineering from the Technical University “Alfonso X El Sabio" of Madrid. His fields of study are related to civil engineering and urban planning.

He has developed more than one hundred urban planning projects and currently he is the chief of the Leganes City Council Department of Works and Maintenance, in Leganés (Madrid). He is the author of the article "Computer Concrete Beans and Pillars Calculations" published in June of 1998, issue number 253 Cimbra Magazine. Mr. Garcia is a member of the Spanish ASCE.

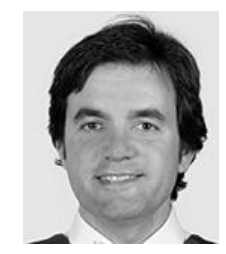

Jose María del Campo was born in Spain in 1970. He is a PhD in civil engineering from the Technical University of Madrid (UPM). His fields of study are related to civil engineering equipment and construction planning.

He has collaborated in more than one hundred projects and construction sites. He is the author of 12 books related to machinery and auxiliary equipment. $\mathrm{He}$ is currently a professor in the Civil Engineering College at the UPM.

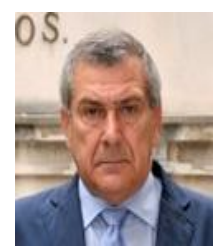

Juan A. Santamera was born in Spain in 1953. He is a $\mathrm{PhD}$ in civil engineering from the Technical University of Madrid (UPM).

$\mathrm{He}$ is the president of the Spanish Asce, and Urban planning professor in the Civil Engineering College at the UPM. He is the author of the book "Introduction to the Urban Development," $3^{\text {rd }}$ ed. Ed. published by Civil Engineer Association, 2001. 